\title{
Urban transformations in state squares of the Baltic Sea region
}

\author{
Inesa Alistratovaitė-Kurtinaitienè, Vilnius Gediminas Technical University, Lithuania
}

\begin{abstract}
The square is a traditional element of urban fabric and, as a rule, a focal point of its urban spatial structure. It is not only an element that reflects the maturity of an urban structure but also transcends the sociocultural experience of society (heritage). It has been almost 30 years since the restoration of Baltic states independence, but the squares in the central parts of towns and cities have not acquired a complete result. The development of squares remains a burning issue in the structural aspect (the form, the ratio of a square and surrounding build-up), in the compositional aspect (formation of continuous building frontage, respective principles of the build-up, etc.), in the functional aspect (the rank of a square among other urban public spaces, etc.). This question is frequently raised at various levels (professional, political, social), just like the issue of status (both physical and social). This is especially true for the capital Vilnius of Lithuania, which still does not have the image of the stately representative square. The assumption is made that the comparative method can provide more information and will look at the topicality from another point. Therefore, this article presents a comparative study of the 4 countries of Baltic Sea region - Estonia, Latvia Lithuania and Poland. The capital cities of countries from a pre-defined region with similar culture, have been selected. They have a common feature - post socialist status in the Europe. The above discusses the main aspects of the formation of squares, reveals certain parallels between the main items of the capitals of Baltic Sea region countries and discusses the possible further development of the paths.
\end{abstract}

Keywords: state square, central part of the city, Baltic Sea region, post-socialist city

\section{Introduction}

In case of urban development in Lithuania, the period until 1990 can be described as the most intensive phase of spatial transformations, including alterations of inner public spaces. It progressed despite the fact that at that time the priority was laid on the territorial expansion of cities and towns. However, since 1990, although the goal of inner urban redevelopment is officially declared, the redevelopment process of urban public spaces is stagnating. The major squares of larger cities are perfect examples of this situation. Although the need to transform urban squares has been a frequently discussed topic for almost three decades, majority of already completed projects of redevelopment of major squares in smaller towns and, to some extent, rehabilitation of secondary urban public spaces in larger cities highlight a strange trend. Primarily, it's a sign of shifting approach towards redevelopment of public spaces, which emphasises smaller aesthetical interventions (e.g. new sculptures, other technical improvements) over solving fundamental issues of frequently deformed urban tissue of post-socialist cities. Although ideological monuments were dismantled in all major squares of Lithuanian cities, the morphology of these public spaces, as well as their spatial configuration retain some properties of previous socio-political order. During recent decades these urban spaces didn't acquire new spatial qualities. Furthermore, their spatial unity and compositional arrangement was violated by the removal of former elements.
Given the fact that changes in the transformation of squares have been experienced by all post-Soviet and socialism-marked countries, the scale of such change is very different, however. In the case of Lithuania, the most vivid example of such a square in major cities is the Lukiškès square in Vilnius, where, after a long debate, disagreements and a period of contests, today, for the first time after 1990 , changes are finally taking place - the square is about to be transformed (alas, perhaps only aesthetically, but not in terms of space morphology). As during this period much attention has been devoted to research of the historical development of the Lukiškès square (and it is obvious that knowledge of history alone does not guarantee qualitative transformation), practical examples and know-how are referred to. An ambitious goal has been set to compare squares of similar evolution in the context of common European culture, focusing more on the character of the form of the squares, their identity reflecting contemporary social, economic and political situation. The assumption is made that the comparative method can provide more information and will look at the topicality from urban transformation point, highlighting their main spatial and social qualities as possible factors of their redevelopment.

\section{Platform for evaluation of squares}

\section{Concept of a city square}

From a physical point of view, urban spatial structure of cities is formed out of three major components: built-up spaces (blocks and quarters), 


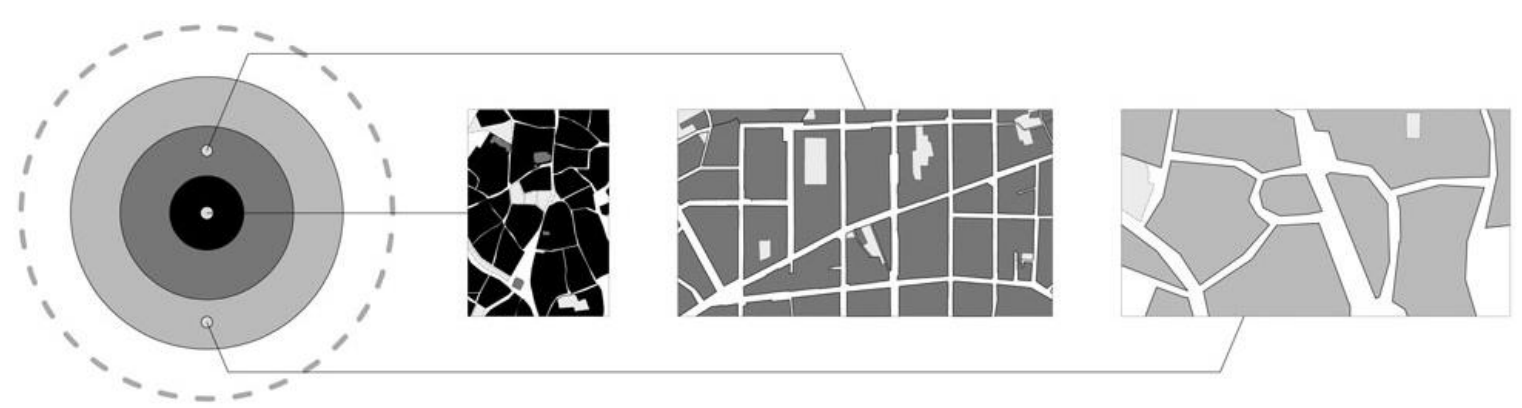

Fig. 1. The plan of the hierarchy of the city parts and the urban structure of separate parts Created by the author.

open spaces (public and green spaces) and urbanarchitectural complexes. The overall impact of these three elements is defined as urban fabric. Its intrinsic spatial qualities are an indicator of maturity of cities. Through differences in the relationship between built-up and open spaces, urban places acquire their unique character (identity). However, the system of open urban spaces plays an essential role, acting as a spatial framework, which bound all the other elements into complex urban tissue. Consequently, the urban squares receive most of the attention, because of their exceptional spatial features (nodal element of urban system) and socio-cultural potential (places of representation of political or cultural ideals, as well as expression of social ideas). As a result, for the purpose of this article, the urban square is defined as an element of a city's public relations that performs a significant role as a city's focal point in the network of its public spaces. It is a place for various social, economic, political interchange.

\section{Importance of the hierarchy of city parts}

There are several common criteria characterizing a square [1]. Seeking to understand the element of a square, it is important to note that it is inevitably connected and blends into the surrounding environment. Thus one of its major aspects is its spatial location. In the hierarchy of different city parts, every part has its public space structure pertaining to it (Fig. 1). Among others are city squares that reflect the present character of public spaces as well as the status of a certain city part. In spite of that, squares remain nodal points of infrastructural, social and economic intersections that can be entered from different sides. But located in different parts of cities, squares differ from place to place. The second criterion in understanding the character of a square is its physical dimensions. It is closely connected to the structural parts of a city that differ in their built-up character and its parameters. The third criterion in understanding the character of a square is its social content. Just like the two previous criteria, this one is also closely related to a city's structural parts that differ from each other in their socio-cultural content.

Thus, based on the three criteria, the presence of a square as a public, integrate element testifies of the maturity of the urban morphostructure and public spaces system. Precisely that determines the variety of city squares.

\section{Criteria for a square formulated in professional literature}

Even though a square can be singled out as a separate element of the urbanistic structure, in the literature it is usually researched and evaluated as an integrate part of a city's public spaces. Thus the research usually focuses on the development principles of the urbanistic space, specific compositional-structural solutions. In literature, studies of the square phenomenon can be divided according to the aspects of the evaluation of a square (historical, morphological, structural, social, visual-psychological) with criteria that make them more specific [1].

\section{Selection of squares and the era}

The capitals of the countries from the same geographically defined cultural region, also named as the Central Europe ${ }^{3}$, have been chosen. This article presents a comparative study among capital cities of the closest neighbouring countries Estonia, Latvia, Poland, and Lithuania. The abovementioned countries are united by the restoration of their independence (that most often happened in the squares located in the central parts of the city), the acquisition of the post-socialist status, economic circumstances, etc. The totality of these conditions is mostly reflected in squares in the central parts of the city, which today are recognized as representative spaces of the state.

\footnotetext{
${ }^{1}$ This is Prague (Czech Republic), Tallinn (Estonia), Riga (Latvia), Warsaw (Poland), Vilnius (Lithuania), Bucharest (Romania), Bratislava (Slovakia), Ljubljana (Slovenia), Budapest (Hungary), East Berlin (Germany).
} 
The main historical facts of the squares in the 1st transformation stage. Created by the author.

Liberty square in Tallinn (Estonia)

The square formed as approaches to the old town, as a nodal point which is accessed after passing the old town defensive wall (preserved from the Middle Ages) with a separately forming distinctive town, called the town of Estonians. In the centre of the current square, there was the Harju Tower that has maintained the medieval defensive wall [2], [3].

$$
\text { Freedom Monument square in Riga (Latvia) }
$$

Until the 15th century, the territory of the square was behind the defensive wall. Since the beginning of the 15 th century, many little villages settled around the fortress walls. Gradually they merged and formed the suburbs. In the period from 1559 to 1812 , for example, the Riga suburbs burned eight times, once every 30 years. At the end of the 18th century Riga greatly expanded, absorbing the surrounding villages [4], [5], [6]. Lukiškès square in Vilnius (Lithuania)

Since the middle of the 15th century, it was a field of grass for a long time and, until about the 19th century, it was used as an intersection of roads and paths and a poor pasture. At the end of the 18th century, a striking accent was built in the northern part of the square - a complex that consisted of the Church of St. Apostles Philip and Jacob, a monastery and a hospital [7], [8].

$$
\text { J. Pilsudski square in Warsaw (Poland) }
$$

Since the 15th century, the territory was dominated by forest areas. From the north to the south, there was an old road (the present Wierzbowa and Mazowiecka streets), and the area was called the suburb of Kraków, which was connected by the so-called Saxon Axis (its formation started in 1713 and it is divided into three stages of formation [9]). The direction of this axis is from east to west. It started with the gates of the Krakow suburb to the garden and pavilions, barracks, which had such functions as residential, military and public [10].

\section{Square study sections}

The studied squares are outside the old towns, but in the territory of the central part of a city. Urban transformations of a square are studied in two sections - historical and urban. The study of urban transformations is carried out at 3 levels of urban structure research:

1. in the city context - in which district of the city the square is located;

2. in the system of public spaces of the city district (whether the analysed square is a part of this system);

3. in the local context of the square - in the plan, in the construction of spatial form and in the section.

\section{Transformation of squares \\ from the historical point of view}

Evaluating separately, the urban development of a square can be viewed as contained within a series of sequential phases, namely, initiation, formation, maturity and reformation.

By tracing main innovations and trends, the preliminary length of these stages is identified.

Stage I - the initiative stage (from the 15 th century to the end of the 18 th century) - it is the beginning of the development of the territory, it records the first events related to the use of the territory. The situation of the future squares of all the four cities is similar: the location of a square is in the suburban area: in the case of Warsaw and Vilnius, it is more distant from the kernel of the city and is mainly used as the intersection of roads and paths; in the case of Riga and Tallinn, the space of the current square used to mark the entrance to the city performing the function of the city gate, where some of it is situated on boundary of the fortifications. As a city expanded beyond the gate, the square became an integral spatial element of the territory. The accents important for the territory emerged at the approaches to all the 4 future squares (in Tallinn, the Harju Tower, in Riga, the city gate to the then town, in Vilnius, St. Jacob's Church, in Warsaw, the complexes highlighting the Saxon Axis) (Table 1).

Stage II - the formative stage (the 19th century) - it is an ever-growing use of the territory, where there is a need to perform both social (marketplaces) and cultural (exhibitions, pavilions) and state (parades) activities. These activities are closely linked to the evolution of cities and of the state itself. Both in the case of Riga and Tallinn, the square performed the function of accessing the city surrounded by the defensive wall. This access, in the case of Riga, was reinforced by a bridge over a fragment of defensive fortifications (the latter were dismantled and turned into a park in accordance with the tendencies prevailing at that time in Europe), and in the case of Tallinn it became a hay and timber market, because the volumes of such goods were an obstacle to trade in them in the town itself (in its inner squares). The trading function formed in the case of Vilnius, too. Alongside it, other socialcultural activities were also developed (exhibitions of agricultural produce, pavilions were built for the crowding function - circus, showing movies). In the case of Warsaw, the significance of the Saxon Axis that considerably grew for political considerations was respected by construction of a new palace and reconstruction of the old one, 
The main historical facts of the squares in the 2nd transformation stage. Created by the author.

\section{Liberty square in Tallinn (Estonia)}

In the middle of the 19th century, the site of the hay and timber market was settled behind the medieval defensive wall. The territory was increasingly resembling a transit area from the Old Town to the New Town. In 1860, a significant building - St. John's Church - was built in the perimeter of the square [3], [11].

$$
\text { Freedom Monument square in Riga (Latvia) }
$$

In the 19th century, the removal of defensive fortifications already became a usual procedure in other European cities. Therefore, after cancellation of the fortress status in 1857, the defensive fortifications became a protective old town area and were converted into a park (according to the examples of Gothenburg, Bremen, Vienna, Krakow). By 1863, land mounds, bastions were demolished, the water ditch was narrowed. A bridge was built that linked a newly built modern district (today's New Town) with the main street - the boulevard and the dominant 19th century buildings [5], [6].

$$
\text { Lukiškès square in Vilnius (Lithuania) }
$$

At the beginning of the 19th century, the Lukiškès territory was a suburb with an essential and distinctive feature - a vast territory with rarely urbanized spaces. In 1860, the territory was transformed into a big marketplace and started to be integrated into the city. At the end of the 19th century, exhibitions of agricultural produce started to be organised in the square, a pavilion was built, where circus performances, demonstration of movies took place. Lukiškès marketplace was used for various purposes. During the uprising of 1863-1864, death executions were publicly performed in the square [7], [8].

$$
\text { J. Pilsudski square in Warsaw (Poland) }
$$

In the plan of the 19th century, it was the central point of the Warsaw city territory, making it the basis for expansion of the city to the west. In 1815-1816, the square was paved for the purpose of organizing parades. In 1839-1842, the Saxon Palace was restored - the central part of the building was replaced by a colonnade of Classicism style, which turned into a connection between the square and the Saxon garden. In 1841-1894, a monument to the Poles was erected on the square. New buildings emerged in the approaches to the square. At the end of the 19th century, a cathedral (in Byzantine style) was built on the square, and a separate bell tower was located near it. After 1890, in the eastern part of the square, a building of the Russian regional headquarters was built, later the headquarters of military courts were constructed [9], [10].

TABLE 3

The main historical facts of the squares in the 3rd transformation stage. Created by the author. Liberty square in Tallinn (Estonia)

To celebrate the 200th anniversary of the Russian rule in 1910, the square was named Peetri plats (Peter Square) and a bronze statue of Peter the Great was erected. Peter was pulled down during the early years of Estonian independence (in 1922), and that is when the square was renamed the Liberty square. Most of the built-up around the square is dated 1920-1930: Gloria Palace Cinema (1926), The grimy Palace Hotel (1925). Parades and other big events started to be organised on the square. Buildings of Stalinism style appeared on the northern side of the square. During the Soviet period, the Liberty square was known as the Victory square [3], [11]. Freedom Monument square in Riga (Latvia)

The remains of the city's fortification system were turned into a park - called the Bastion Park on one side, the National Gallery Park on the other side (although it is also built on the remains of the fortification system). The bronze statue of the Russian Emperor Peter the Great was built on the site of the current square as a sign of the Russian Empire. After dismantling it, in 1935, the symbol of unity and freedom of the Latvian nation was unveiled - a sculpture 42 meters high, as a sign of the commemoration of the fallen in the fight for freedom. In Soviet times, the meaning of the Freedom Monument was interpreted according to the system of the then government [6].

$$
\text { Lukiškès square in Vilnius (Lithuania) }
$$

At the beginning of the 20th century, the square shrank significantly. The avenue of St. George (currently, Gedimino Ave.) that started to be formed in 1836 was finally formed at the beginning of the 20th century. In the approaches to the square, built-up of the Secession style emerged forming the perimeter of the square. In 1939, the marketplace was moved out of the square and was settled next to the Church of St. Jacob and Philippe. The southern part of the square began to be used for parades. In the post-war period, in 1949-1952, according to the design of the architect V. Mikučianis, the square was reconstructed, incorporating the paths and other landscaping elements formed before the war. In 1920, during the Polish occupation, the square was renamed after J. Pilsudskis, and in the Soviet occupation period it became the Soviet square, later the Lenin square with a Lenin monument [7], [8], [12].

\section{J. Pilsudski square in Warsaw (Poland)}

The square was always a composite element on the Saxon Axis from west to east, from the west side it was separated from the Saxon gardens (1666-1939) by the Saxon Palace (which was the Warsaw Lyceum in the 19th century, the Polish General Headquarters during World War I), and from side of the main street, two structures of atrium type were formed, where 1 building corresponded to 1 block. The tower and the cathedral were demolished during World War I and the Saxon Palace was demolished during World War II. The remaining fragment of the colonnade of the palace dated 1925 contains the Tomb of the Unknown Soldier dedicated to the fallen in the fight for the independence of Poland. The square was to be called the Saxon Square, it was renamed after J. Pilsudski after World War I, and it became the Victory Square after World War II. In 1979, the Pope St. John Paul II held the Holy Mass here [9], [10], $[14]$. 
The main historical facts of the squares in the 4th transformation stage. Created by the author. Liberty square in Tallinn (Estonia)

After the restoration of Estonia's independence in 1990, the square was essentially used as a public parking lot [13]. In 2007, the Bronze Soldier monument located here was moved near the cemetery of the soldiers of the Soviet Army. In 2008, the reconstruction of the square began, where in 2009 on the western side of the square the Liberty Cross commemorating the Estonian War of Independence in 1918-1920 was unveiled. The name of the square used in the interwar period was restored - the Liberty square [11].

Freedom Monument square in Riga (Latvia)

After 1992 the version of the meaning of the monument was restored on the Latvian scale. The former bridge was admitted to be part of the square only after 1990, when a part of the street around the monument, which is about $200 \mathrm{~m}$ long/wide, was turned into a pedestrian street [6].

Lukiškès square in Vilnius (Lithuania)

After dismantling Lenin's monument in 1991, there has been a lot of discussion in the society about the purpose of this space. Since 1999, there have been eight contests for the square reconstruction designs and monument ideas. In 1999 , the Seimas passed a resolution that recognized the Lukiškès square as a representative square. On 2 November 2017 , after a year and a half of reconstruction, a renovated Lukiškès square was opened, where a landscape design of the territory was implemented, replacing the composition established in the Soviet era. However, no monument still exists as a mark to commemorate the past and the present [7], [8], [12].

$$
\text { J. Pilsudski square in Warsaw (Poland) }
$$

After 1990, excavations were carried out on the square - the remains of the Saxon Palace were uncovered, but everything was covered again in the wake of the global economic crisis. It is planned to restore the building as the Warsaw city hall, but works have been stopped indefinitely [14]. After 2006, a monument was built - a cross. After 1989, the interwar name of the square was restored - Jozef Pilsudski square.

changing its function. By completing this axis from east to west, a cathedral of Byzantine style with a bell tower was built in the very space of the square, in the case of Tallinn, St. John's Church was built at the approaches to the square (Table 2).

This stage is one of the wider stages in the development of the squares under consideration. The function developing in this stage and the emerging accents in the future squares seem to have formed the basis for the identity of the territory, and compared with the future squares of Vilnius, Tallinn and Riga, this stage in the Warsaw case was the most active and most mature in the formation of voluminous spatial composition. In both the case of Riga and Tallinn, the space itself was more of a transit nodal point, and in the case of Warsaw and Vilnius, it was the focal point of the emerging new part of the city.

Stage III - the maturity stage (from the beginning of the 20th century to the 1990) - it is one of the most active periods in the evolution of the squares in various aspects of activities (social, cultural, political, etc.). At this stage, the volumetricspatial features of the territory are finally consolidated, the image of the future representative space on the national scale is formed, especially in the cases of Riga, Tallinn and Vilnius. Individual buildings emerge as organizers of the territory, which establish a significant role of the space in urban fabric. Like other stages, this maturity stage is similar, but is not the same for the chosen squares in the Baltic Sea region: in the case of Tallinn, the formation of the perimeter of the square ends with built-up framing the space, and, in the case of Riga, the space of the square begins to be marked with monuments related to the political situation of the state; in the case of Warsaw, the volumetric spatial composition of the square is most radically altered, although the axial composition is preserved, but it no longer has its main accents - the tower and the cathedral and the Saxon Palace (both of which, that became signs of the maturity of the state, were demolished during wars); in the case of Vilnius, the perimeter of the square is consolidated by laying of the adjacent representative street, groups of buildings forming it and the dominant element on the Tauras' Hill which fixes the north-south axis, while the space of the square, as in the case of Riga and Tallinn, is marked with political symbols (Table 3 ).

Stage IV - crisis followed by reformation or dissolution (from 1990 to the present day) - it is a stage during which criticism about the representative nature of the squares has grown, and the theoretical foundations of the squares are being redefined. The latter are becoming another beginning in the further development of the squares by consolidating the formed cultural heritage. This stage in the formation of the image of the squares can be described as a period of crisis, which ends with the dissolution or reformation of the previous situation (political vacuum) - the need to become liberated and eliminate imposed clichés (marking the political regime) on the democratic path of the country. One of the signs of maturity in a square is the continuity of its formation, which is happening in all the four countries. In the case of Riga, the version of the meaning of the monument was restored on the Latvian scale and the space of the bridge was recognized as a representative space, and behind that space, as in the case of Tallinn and Vilnius, monuments by their essence alien to the nation were 
dismantled. Reconstruction of the space in the representative squares of the latter cities has been performed: during the reconstruction in Tallinn, the volumetric spatial composition of the square was substantially revised - it was decided to mark the significant signs (fragments of the defensive wall and the Harju Tower) that had vanished in the evolution of the territory and add a sign signifying events important for the statehood; which is the opposite in the Vilnius case where the volumetric spatial composition remains unchanged, and the signs have become a never-ending object of the dispute. In the case of Warsaw, the volumetric spatial composition of the square was planned to be restored, but the plan of radical reconstruction of the square was halted by the global economic crisis, therefore the compositional quality of the square space remains unchanged, a sign marking events significant for the nation has appeared. All squares have recovered their names that gained meaning in the evolution period important for a relevant country (Table 4).

\section{Transformations of the squares from the point of view of urban analysis}

\section{In the context of a city}

Two aspects are important for assessing the current situation in the context of a city - the location of the square in the urban structure of the city and the category of the square in the system of city squares. According to the location, all the squares in question are located in the central parts of the city, only in the case of Riga and Tallinn, the squares in question are along the boundary of the Old and New Town districts, in the case of Warsaw and Vilnius - in the central part of the city New Town district. According to the status of the square in the city - all the four squares have the state representative status (the main square of the city) (Fig. 2).

Studying the squares in the system of public spaces of the city's district, the study involves three aspects: historical consistency, functions, and connections to other public spaces. According to historical consistency, all the squares under consideration are a methodically formed structure based on the principles of regularity: in the case of Riga and Tallinn, the square from the old town's side is an independently formed structure, an irregular network of streets; from the new town's side - it is a methodically formed structure based on the principles of regularity. The square is regular, close to the form of a rectangular. In the case of Warsaw and Vilnius, the square was methodically formed according to the 18th century (in Warsaw) and 19th century (in Vilnius) principles of regularity with remnants of suburban structures on the inside.
The area is a regular, square shape close to the trapezium (Table 5).

When examining the aspect of the function, attention is paid to what kind of square it is according to its function, what possibilities the approaches to it give, since multi-functionality of a square is a prerequisite these days. The Freedom Monument square does not have this feature because it is a mono-functional, transitional space of a street type that connects the old and new town parts, and parks with a public function make up to $75 \%$ of the perimeter. In the case of the other three squares - the squares do not have the exact function (private and public interests interconnect in the environment restricting the squire, forming a code of multifunctionality and signs of cultural life), sometimes the city citizens' events take place in the squares: in the Liberty square the public function makes up to $60 \%$ of the perimeter, the largest part of the perimeter is the territory of St. John's Church, there are remnants of the old tower under protective glass blocks; in J. Pilsudski square - it makes up to $63 \%$ of the perimeter, and the remaining $37 \%$ form adjacency to the State park; in the Lukiškès square there is both the public function $-43 \%$ of the perimeter, and the recreational one (this is determined by the alleys of trees growing along the perimeter of the square), besides one of the sides of the square meets the complex of St. Jacob's Church.

The connection of the square with other public spaces (or with important elements/adjacencies of the city such as the river, other focal points, etc.) is a very important condition for the multi functionality of the square. In the case of Riga, the Freedom Monument square is a transitional streettype space that connects the network of the old town's public spaces with the new town's network. It leads into the main composition axes of different city structures. In the case of Tallinn, the Liberty square is a nodal point focusing on the old town's public spaces and partially continuing towards the new town. 8 streets and routes converge into the square. In the case of Warsaw, J. Pilsudski square is neither a nodal point nor a transit area. The space of this square, by its compositional structure, corresponded to the function of a yard, which could be accessed passing through the buildings, and was an integral part of the ensemble of both the park and the palace. Therefore, having evaluated this fact, the absence of an enclosed perimeter of the square makes it more a brownfield land that a nodal point, where action is only episodic (8 streets converge into the square). In the case of Vilnius, the Lukiškès square is positioned next to the representative street of the city, the axis of which has objects of state importance. 11 streets converge into the square (Fig. 3). 


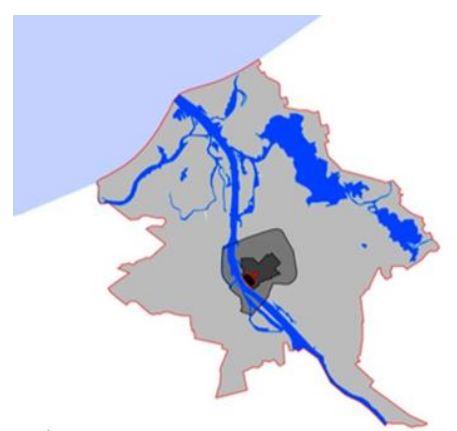

A

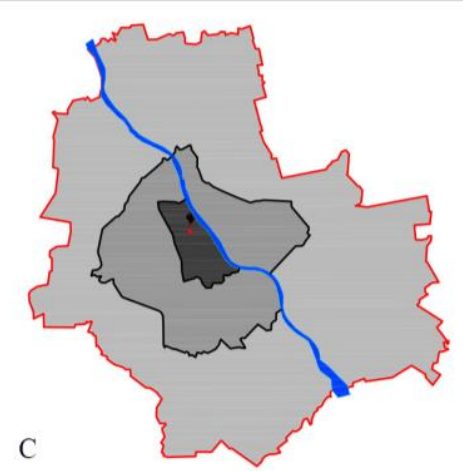

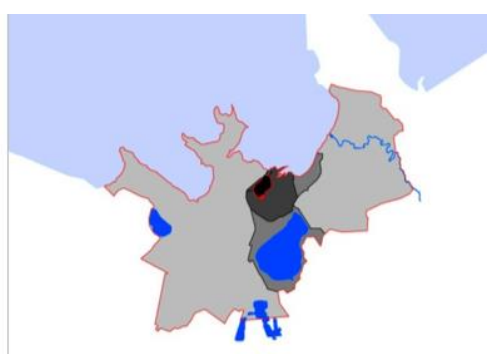

B

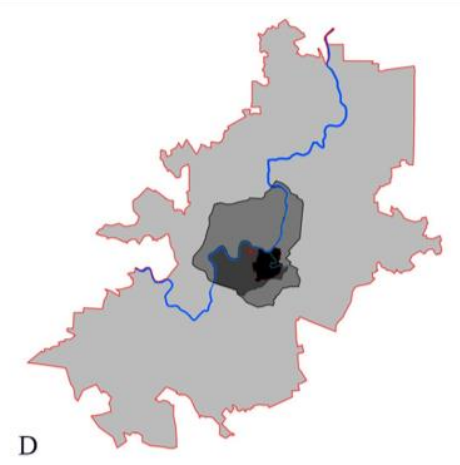

Fig. 2. Location of the squares in the context of the city: A-Riga, B-Tallinn, C-Warsaw, D-Vilnius. Created by the author.

TABLE 5

Sizes and proportions of the squares in question. Created by the author.

\begin{tabular}{|c|c|c|c|}
\hline $\begin{array}{c}\text { Liberty square in Tallinn } \\
\text { (Estonia) }\end{array}$ & $\begin{array}{c}\text { Freedom Monument } \\
\text { square in Riga (Latvia) }\end{array}$ & $\begin{array}{c}\text { Lukiškés square in Vilnius } \\
\text { (Lithuania) }\end{array}$ & $\begin{array}{c}\text { J. Pilsudski square in } \\
\text { Warsaw (Poland) }\end{array}$ \\
\hline $\begin{array}{c}\text { Size } 75 \mathrm{~m} \times 110 \mathrm{~m} \rightarrow 0.83 \\
\mathrm{~km}^{2}\end{array}$ & $\begin{array}{c}\text { Size } 181 \mathrm{~m} \times 72 \mathrm{~m} \rightarrow \\
1.30 \mathrm{~km}^{2}\end{array}$ & $\begin{array}{c}\text { Size } 190 \mathrm{~m} \times 210 \mathrm{~m} \rightarrow \\
3.9 \mathrm{~km}^{2}\end{array}$ & $\begin{array}{c}\text { Size } 100 \mathrm{~m} \times 175 \mathrm{~m} \rightarrow \\
1.75 \mathrm{~km}^{2} \\
\text { (proportion } 1 \div 1.8)\end{array}$ \\
\hline
\end{tabular}
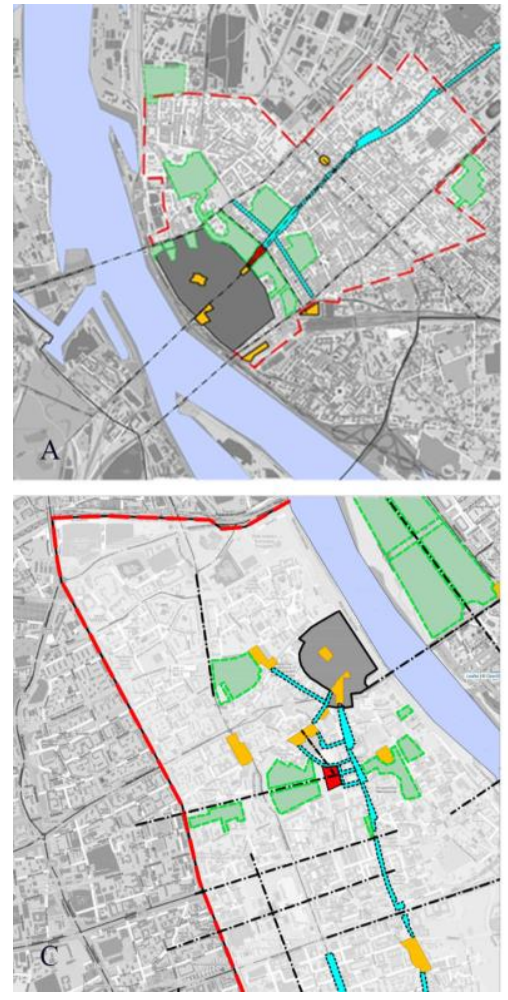

B

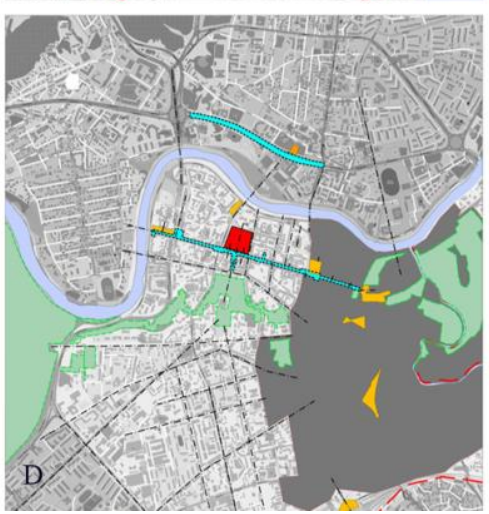

Fig. 3. Squares in the system of public spaces of the district: A-Riga, B-Tallinn, C-Warsaw, D-Vilnius. Created by the author. 


\section{Physical parameters of the square in the plan}

When comparing physical parameters in the plan of the square, the scale of modular network, visual relations and volumetric-spatial composition are distinguished. The first aspect is determined by the module of the land plot, in some places it is even referred to as a modular unit, which has the scale of the built-up type from the spatial point of view. It is determined not only by the natural laws of the land market, but also by the boundaries of the land plots themselves. In the case of Riga, in the Freedom Monument square, the avenues of access are dominated by planned perimetrical built-up (medium and large scale buildings). The square's scale partially fits the present scale of the modular network. Proportions are those of a street, not a square (the average size of blocks is $1.2 \mathrm{~km}^{2}$, the territory is $1.3 \mathrm{~km}^{2}$ ). In the case of Tallinn, in the Liberty square, planned, methodological perimetrical built-up (medium and large scale buildings) is dominating. The square's scale is adequate to the settled structure and matches the space that is not built up (av. size $-1.3 \mathrm{~km}^{2}$, square's size $-0.83 \mathrm{~km}^{2}$ ). In the other two squares, planned, methodological built-up with large buildings (in J. Pilsudski square) and with large and small scale buildings (in the Lukiškès square) is dominating, which is divided into small / medium - private and large - state built-up. The space exceeds average scale of modular network in J. Pilsudski square for $\sim 2$ times (av. size $-1.2 \mathrm{~km}^{2}$, square's size -2.4 $\mathrm{km}^{2}$ ), and in the Lukiškès square for $\sim 1.8$ times (average size of blocks is $1.7 \mathrm{~km}^{2}$, the square's territory is $3.9 \mathrm{~km}^{2}$ ).

The second aspect is the assessment of visual connections from the square (variety of perspective, visual pictures). According to it, in the case of Riga, 2 dominating multi-plane perspectives from the Freedom Monument square prevail: 1 - towards the old town with towers in the background; 2 - towards the New Town with "Radisson Blue" hotel. In the case of Tallinn, 4 dominating perspectives from the Liberty square prevail: 1 single-plane open nominal perspective with clearly expressed compositional connection towards the other side; 2 - multiple-plane nominal perspective with the Liberty statue and a defence tower in the background; 3 - two frontal perspectives. In the case of Warsaw, there are several perspectives from J. Pilsudski square: 1 - an open nominal perspective with a potentially clear compositional connection with the surrounding area from the west to the east (the Saxon Axis), as well as the high-rise buildings in the southwest; 2 - an open nominal perspective without clear compositional connections with the surrounding area. In the case of Vilnius, two dominating perspectives from the Lukiškès square prevail: 1 - single-plane open perspective with no clear compositional connections with the surrounding area; 2 - frontal nominal perspective (Fig. 4).

The third physical parameter is the volumetricspatial composition of the square - it is the character of nominal spaces, the presence of a dominant or important structure in the square, respected axes, etc. In the case of Riga, the dominating axis-type composition with mono-dominant and a space with the Freedom Monument in the middle of square prevail. Park trees make a natural formant and nominal frame with "Radisson Blue" hotel in the background (towards the New Town). In the case of Tallinn, there are several spatial dominants: 1 - St. John's; 2 - Liberty Cross statue with a defence tower as the axis; 3 - one segment of the square is formed by a ramp to the mall thus strengthening the nominal perspective of the buildings on the other side of Carl's boulevard. In the case of Warsaw: dominating axis-type composition from the east to the west with the remaining small fragment of the former built-up (with the Tomb of the Unknown Soldier) between the park and the space of the square; on the eastern side of the square there is a public establishment (Warsaw Garrison Command) and Europe hotel; on the northern side there is a commercial building Metropolitan with the National Grand Opera Theatre, behind which one can see the City Hall tower; on the southern side there is the Polish Association of Building Managers and the Zachęta National Gallery of Art, behind which one can see the Holy Trinity Church. In the case of Vilnius, there is a couple of spatial dominants: 1 - the Church of St. Jacob and St. Philip of late Baroque style; 2 - the Court, the Music Academy, the former Trade Union building on Tauras' Hill make up one compositional complex.

\section{Physical parameters of the square in a spatial structure and in a section}

When comparing physical parameters in the spatial structure and section of a square, the compositional ratio of space and dominants and psycho-emotional charge (field) are relevant. Frequently, the ratio of width to height as a certain golden section for identifying the scale of the square is given when examining square proportions in the professional literature, especially in the old town parts of cities [1]. Examining squares in the central part of a city (between the old town and new districts) - it is an element of a semi-formed morphostructural system, which is often not complete. It is not the shape of the square that is changing, but its physical parameters in the perimeter of the square built-up, both on the layouts and in the inner spaces of the blocks - approaches to the square. In the case of Riga and Tallinn, 

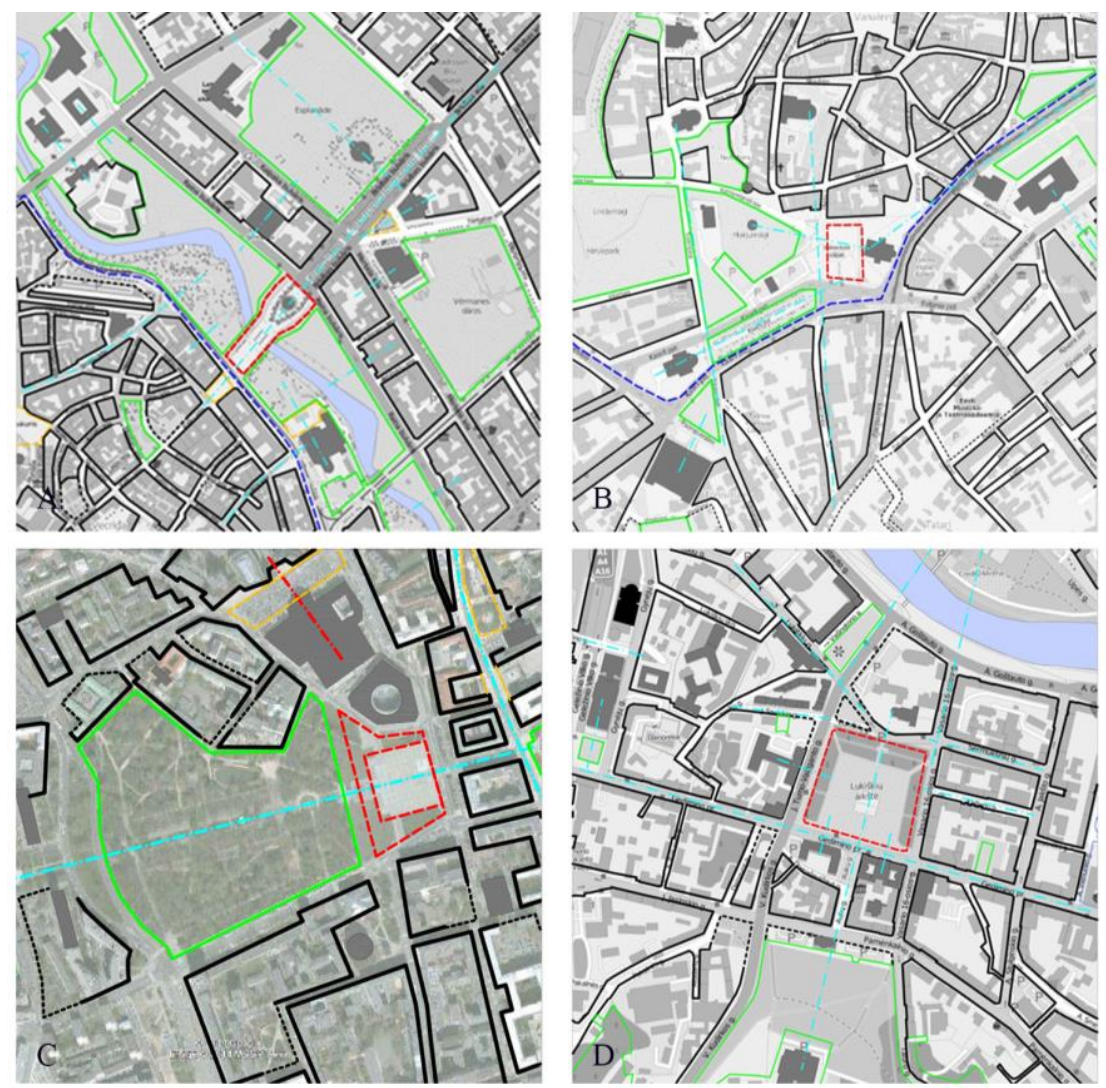

Fig. 4. Squares in the local context-on the plan: A-Riga, B-Tallinn, C-Warsaw, D-Vilnius. Created by the author.
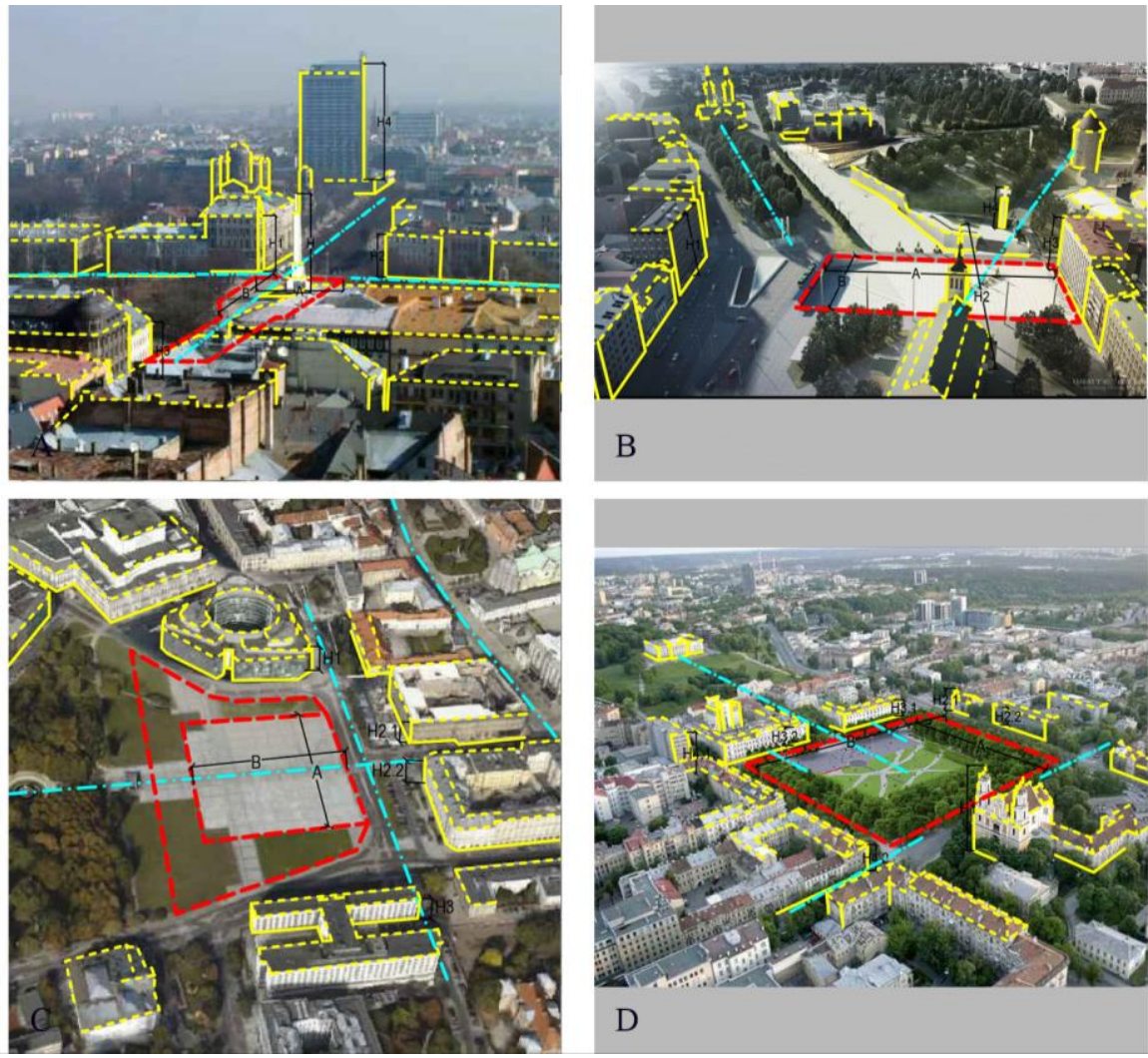

Fig. 5. Squares in the local context - in the construction of spatial form: A-Riga, B-Tallinn, C-Warsaw, $D$-Vilnius Created by the author. 
formation of the perimeter is complete (the Freedom Monument square and monument proportions are $1 \div 1.2$; the Liberty square and formant proportions are $1 \div 2.5$ and $1 \div 1.2$ ). In the case of Warsaw and Vilnius, the formation of the perimeter is incomplete (J. Pilsudski square and formant proportions are from $1 \div 4$ to $1 \div 10$; the Lukiškès square and formant proportions are $1 \div 12$ ) (Fig. 5).

For the physical parameters of a square in the spatial structure, the psycho-emotional charge is also relevant, which is treated as a physical factor. In the case of Riga, boulevard, that in 1990 was turned into a square, restored significance of the monument on the scale of the country. In the case of Tallinn, the name changed (Victory $\rightarrow$ Liberty), the Liberty Cross was unveiled in 2009. The monument of the Bronze Soldier was dismounted (2007). In the case of Warsaw, the creation of the vision of the square was halted indefinitely, a cross memorial to commemorate the Pope John Paul II was erected in the space of the square, and the name of J. Pilsudski was restored. In the case of Vilnius, the symbol of the Soviet period was dismounted, there is a clear vision of further development, but still no new elements.

\section{Conclusions and discussion}

The presented sections of the study with separate aspects of evaluation make it possible to compare the squares and make various conclusions about the morphology of the space formed in them. However, it is obvious from the presented study that the content of these squares reflects the history not only of the city but also of each country. As elsewhere, it is clear that squares can be regarded as a certain phenomenon that accumulates various social phenomena or events, and therefore they represent much more than the physical function or purpose of a city space, also conveying the semantic content of events. The transformation process required for a square of this scope is also reflected in aspects of the assessment of the urban space.

The built-up of the central part is mostly determined by the regular planned structure with intensive built-up, high quality of public spaces, accompanied by a visually completed (transformed according to a single aesthetic-compositional ideology) urban structure with built-up proportions characteristic to it. In the central parts, a great deal of both public and private interests are often intertwined. The square in the central part (between the Old Town structure and the new districts) is an element of the semi-formed morphostructural system, which is still being improved as the case studies show. It is not the shape of the square that is changing, because it is usually an undeveloped block (unless spatial semantics is disrupted as in the case of Warsaw), but its physical parameters in the perimeter of the square built-up.

The performed study of transformations makes it possible to compare the quality of the selected squares. Historically, in the case of Warsaw, the space of the square began to form much earlier than in the cases of Riga, Tallinn and Vilnius. From the urban point of view, both in terms of location, its modular network scale, and its connection with other public spaces and the compositional relationship of space and dominant elements, the squares can be grouped into two groups: 1 - Riga and Tallinn squares; 2 - Vilnius and Warsaw squares. If, in the case of Tallinn, the Liberty square is a nodal point in the urban structure, in the case of Riga, the Freedom Monument square is a transit area from the Old Town to the New Town. Meanwhile, in the case of J. Pilsudski square in Warsaw and the Lukiškès square in Vilnius, these are focal points of the new district. Both the latter cases are also close in the size of the square, which exceeds the area of the average surrounding block.

Thus, all the four cases of squares have many similarities, but they also have differences in both the historical and urban study sections. These squares with the representative status are exceptional not only on the city scale but also on the scale of the whole country, therefore, they should reflect not only the local morphology of the spaces, but also the cultural national consciousness. It is also a sign of a nation's identity, it is necessary to recognize it eliminating defects in common and well-formulated criteria. From this perspective, the Lukiškès square is no exception in this context. The path of its transformation shows that it should become a significant spatial nodal point both in terms of its status (state square) and in the overall system of urban public spaces of the city. The adjacency of Gedimino avenue represents the whole historical path (from the beginning of the formation of the state and the city to the present day), and the Lukiškès square is just a part of this history, where in order to give it its final meaning, a sign symbolizing a certain historical stage is required.

\section{References}

1. Alistratovaitè-Kurtinaitienè, I. (2015) The square as a type of urban space. Between social functions and spatial dimension [in Lithuanian]. Acta Academiae Artium Vilnensis, No. 76, p. 71-103.

2. Vabaduse väljak [online 12.06.2018.] https://et.wikipedia.org/wiki/Vabaduse_v\%C3\%A4ljak.

3. Kadakas, V. Heinaturg - Peetri plats - Vabaduse väljak, 2009 [online 12.06.2018.] http://aerling.blogspot.com /2010/03/heinaturg-peetri-plats-vabaduse-valjak.html. 
4. Apartments in Riga / Latvia, historic building Kempel House on Gertrudes street [online 13.06.2018.] https://akas8.com/en/about/history/.

5. 24 Grēcinieku Street [online 13.06.2018.] http://www.fashionmuseumriga.lv/eng/kaleidoscope/the_house.

6. Žemaitis, A. History of Riga [online 13.06.2018.] http://www.onlatvia.com/history-of-riga-206.

7. Jogèla, V., Meilus, E., Pugačiauskas, V. (2008) Lukiškès: from the suburbs to the center [in Lithuanian] (Lukiškès: nuo priemiesčio iki centro). Lietuvos istorijos institutas, Vilnius: „Diemedžio“ leidykla. 291 p.

8. Zilinskas, E. (2004) Scientific report of urban and heritage research in Lukiškès Square [in Lithuanian] (Lukiškiu aikštės urbanistinių ir paveldosauginių tyrimų mokslinè ataskaita).

9. Archivum Panstwowe m. st. Warszawy. Os Saskaa [online 14.06.2018.] https://www.warszawa.ap. gov.pl/saska/21201.html.

10. Srodmiescie. Dzielnica m. st. Warszawy. Plac marszalka Jozefa Pilsudskiego [online 14.06.2018.] http://www.srodmiescie.warszawa.pl/ulica-248.html.

11. Jaak Juskega kadunud Eestit avastamas 2: Tallinn, Vabaduse väljak, 2016 [online 12.06.2018.] http://forte.delfi.ee/news/juskegaavastamas/jaak-juskega-kadunud-eestit-avastamas-2-tallinn-vabadusevaljak?id=74251389.

12. Daunora, Z. (1998) Urban conditions and opportunities for development of Lukiškès square and its environment [in Lithuanian] (Lukiškių aikštės ir jos aplinkos urbanistinès sąlygos ir plètojimo galimybès). Urbanistika ir architektūra, Vilnius, XXII tomas, Nr. 2, p. 64-76.

13. Vabaduse väljak, Tallinn (Estonia), 2010. Conversion of a square formerly used as an open-air car park into a space that can be used for multitudinous events. [online 12.06.2018.] https://www.publicspace.org/works/-/project/f082vabaduse-vaeljak.

14. Plac Pilsudskiego. Forum rozwoju Warszawy. Nowa koncepcja uporzadkowania glownego placu stolicy [online 14.06.2018.] http://www.forumrozwoju.waw.pl/placpilsudskiego/os.html.

INFORMATION ABOUT THE AUTHOR:

Inesa Alistratovaitė-Kurtinaitienè is an architect-urban designer, $\mathrm{PhD}$ (2005) and Assoc. Professor (2009). Since 2004 participates in pedagogical activities of Department of Urban Design (teaches theoretical and practical disciplines for bachelor and master students). Since 2005 works as researcher at Urban Research Laboratory, where she's engaged in execution of individual scientific projects, research commissions, as well as preparation of architectural and urban projects. Research interests: urban structure and various aspects of its transformation; urban morphology; protection and development of visual identity. She has published over 20 scientific articles and other papers. She has presented her research in 18 international and national conferences. I. Alistratovaitè-Kurtinaitienè has cooperated with foreign institutions in preparation of several H2020 project proposals. As an expert she has participated in several international workshop. As representative of Department of Urban Design participated in the international seminar. She also has visited and lectured at institutions of higher education in other European countries. Since 2014 she's engaged in expert activities as member of 1st Cultural Heritage Assessment Board within Department of Cultural Heritage under the Ministry of Culture.

Kopsavilkums. Laukums ir tradicionāls pilsētas uzbūves elements un, kā likums, fokālais punkts pilsētas telpiskajā struktūrā. Tas ir ne tikai elements, kas atspoguḷo pilsētvides briedumu, bet arī atspoguḷo sociokulturālās sabiedrības pieredzes. Ir gandrīz 30 gadi kopš Baltijas valstu neatkarības atjaunošanas, bet laukumi pilsētu centrālajās dạ̦ās nav guvuši pilnīgu apjomu. Laukumu veidošana palikusi kā karsts jautājums strukturālā skatījumā (forma, novietojums, ietverošā apbūve), kompozicionālā skatījumā (perimetrālās apbūves veidošana, respektējoši principi jaunbūvēm, utt.) funkcionālā skatījumā (laukuma nozīmīgums salīdzinājumā ar citām pilsētas publiskajām telpām, utt.). Jo īpaši šis ir attiecināms uz Lietuvas galvaspilsētu Viḷnu, kurai vēl joprojām nav reprezentatīvais laukums ar cēlu izskatu. Raksts atspoguḷo četru Baltijas jūras valstu - Igaunijas, Latvijas, Lietuvas un Polijas - salīdzinājumu. 